\title{
OPTIMALISASI KEBIJAKAN STANDAR NASIONAL INDONESIA DAN STANDAR KOMPETENSI KERJA NASIONAL INDONESIA BIDANG INDUSTRI KULIT DALAM MENGHADAPI MASYARAKAT EKONOMI ASEAN
}

\author{
Sonny Taufan \\ Politeknik STMI Jakarta \\ Risang Pujiyanto \\ Politeknik ATK Yogyakarta
}

\begin{abstract}
ABSTRAK
Masyarakat Ekonomi Asean (MEA) berlaku tanggal 31 Desember 2015. Hal tersebut di Indonesia memberi implikasi positif yang harus dimanfaatkan dan implikasi negatif yang harus diantisipasi. Permasalahan kesiapan Indonesia dalam menghadapi Arus bebas barang dan tenaga kerja terampil. Penelitian ini merupakan penelitian hukum normatif, dengan pendekatan perundang-undangan. Hasil penelitian menunjukkan bahwa Pemerintah telah menetapkan pedoman untuk peningkatan daya saing nasional dan persiapan pelaksanaan MEA dalam 14 (empat belas) strategi. Strateginya antara lain penerapan Standar Nasional Indonesia dan peningkatan kompetensi tenaga kerja. Penambahan lingkup SNI Wajib dalam Industri Kulit mengacu pada Rencana Induk Pembangunan Industri Nasional Tahun 2015-2035 serta pertimbangan keselamatan, keamanan, kesehatan, atau pelestarian fungsi lingkungan hidup. Peningkatan kompetensi tenaga kerja dilakukan melalui pelatihan berbasis kompetensi dan pendidikan vokasi industri berbasis kompetensi yang diselenggarakan dengan mengacu SKKNI Industri Kulit. Dengan optimalisasi kebijakan SNI dan SKNNI, diharapkan Indonesia memiliki kesiapan lebih baik dalam menghadapi MEA.
\end{abstract}

Kata Kunci: Optimalisasi, MEA, SNI, dan SKKNI

\section{ABSTRACT}

The Asean Economic Community (MEA) is effective on December 31, 2015. It has positive implications for use and the negative implications that must be anticipated. The problem of Indonesia's readiness in the face of the free flow of goods and the skilled workforce. This study is a normative legal research, with the legal approach. The results show that the Government has set guidelines for improving national competitiveness and preparation of the implementation of the MEA in 14 (fourteen) strategies. The strategy is the adoption of the Indonesian National Standard and the improvement of labor competence. The addition of the Compulsory SNI scope in the Leather Industry refers to the National Industrial Development Master Plan Year 2015-2035 and safety, safety, health, or environmental considerations. Increased competence of labor is done through competency-based training and competency based industry vocational education organized by SKKNI Kulit Industri. With the optimization of SNI and SKNNI policies, it is hoped that Indonesia will have better readiness in the face of the MEA.

Keyword: Optimization, MEA, SNI, dan SKKNI 


\section{PENDAHULUAN}

Masyarakat Ekonomi Asean (MEA) mulai diimplementasikan pada tanggal 31 Desember 2015. Melalui MEA, negara anggota memiliki kesepakatan bersama untuk mengintegrasikan ekonomi dengan tujuan antara lain meningkatkan daya saing kawasan dan mendorong pertumbuhan ekonomi. Pembahasan mengenai MEA dimulai saat KTT ke-9 ASEAN di Indonesia dimana para pemimpin negara ASEAN saat itu menyepakati Bali Concord II untuk meningkatkan integrasi melalui perwujudan masyarakat ASEAN yang memiliki tiga pilar, yaitu pilar politik keamanan, pilar ekonomi, dan pilar sosial budaya.

Dalam KTT ASEAN ke-12 di Cebu, para pemimpin negara ASEAN menyepakati Cebu Declaration on the Acceleration of the Establishement of an ASEAN Community 2015 yang mempercepat pembentukan masyarakat ASEAN dari tahun 2020 menjadi tahun 2015 (kemenlu.go.id). Melalui KTT ASEAN ke-13 yang berlangsung di Singapura para pemimpin negara ASEAN menandatangani Deklarasi yang mensahkan ASEAN Economic Community Blueprint (Cetak Biru Masyarakat Ekonomi ASEAN). Cetak biru tersebut yang akan menjadi pedoman bagi semua Negara anggota ASEAN untuk mewujudkan Masyarakat Ekonomi ASEAN pada tahun 2015 dan memuat empat pilar utama, (http://www.kemendag.go.id) yaitu:

a. Single Market and Production Base, dengan elemen free flow of goods (antara lain penghapusan hambatan tarif dan non-tarif; fasilitasi perdagangan; ASEAN Single Window, penentuan standard produk); free flow of services and skilled labour (antara lain regulasi sektor yang jelas, Mutual Recognition Agreement di berbagai profesi) dan free flow of investment (antara lain peraturan yang jelas, kerjasama promosi dan fasilitasi) serta Priority Integration Sectors, dan food, agriculture and forestry;

b. Competitive Economic Region, dengan elemennya kerjasama di bidang competition policy (antara lain kerjasama antar otoritas persaingan usaha), consumer protection (antara lain mekanisme perlindungan konsumen, kerjasama antar otoritas), IPR (antara lain modernisasi proses, notifikasi dan pengakuan, jejaring otoritas penegak HKI), infrastructure development (antara lain transportasi, informasi, energi dan pembiayaan infrastruktur), taxation (jejaring perjanjian bilateral untuk penghindaran double taxation), e-commerce (kerangka kerja harmonisasi infrastruktur hukum untuk e-commerce dan penyelesaian sengketa);

c. Equitable Economic Development, dengan elemen SME development (antara lain mendorong pengembangan UKM, daya saing UKM, dan meningkatkan daya tahan UKM), dan Initiative for ASEAN Integration (IAI); dan 
d. Full Integration into Global Economy, dengan elemen coherent approach towards external economic relations, dan enhanced participation in global supply networks (antara lain meningkatkan nilai-tambah regional, produktifitas dan riset, serta menganut production and marketing best practices).

Pemerintah Indonesia menindaklanjuti kesepakatan cetak biru MEA dengan menerbitkan Instruksi Presiden Nomor 11 Tahun 2011 tentang Pelaksanaan Komitmen Cetak Biru Masyarakat Ekonomi Association Of Southeast Asian Nations Tahun 2011 (InPres Cetak Biru MEA). Melalui InPres Cetak Biru MEA, pemerintah menunjukkan keseriusannya untuk mengimplementasikan MEA. Suroso (2015) menyatakan melalui implementasi MEA di Indonesia.

Indonesia memiliki peluang positif yang dapat dimanfaatkan berupa pasar barang lebih luas, biaya ekspor impor yang lebih murah, pasar tenaga kerja yang lebih luas serta investasinya tanpa ada batasan ruang antar negara anggota ASEAN. Selain peluang, Suroso menyatakan terdapat beberapa kendala yang harus diatasi Indonesia, yaitu 1) mutu pendidikan tenaga kerja masih rendah, 2) ketersediaan dan kualitas infrastuktur masih kurang, 3) sektor industri yang rapuh karena ketergantungan impor bahan baku dan setengah jadi, 4) keterbatasan pasokan energi dan 5) lemahnya Indonesia menghadapi serbuan impor. Sementara itu Direktur Kerjasama Ekonomi ASEAN, Krisnamurthi (2015 : 4) menyatakan bahwa regulasi yang masih tumpang tindih, relatif rendahnya kualitas SDM, serta rendahnya kuantitas dan kualitas infrastruktur adalah faktor yang berpengaruh pada peningkatan daya saing Indonesia di kawasan.

Untuk mempersiapkan Indonesia dalam menghadapi MEA, Pemerintah telah mengeluarkan sejumlah kebijakan, antara lain Instruksi Presiden Nomor 6 Tahun 2014 tentang Peningkatan Daya Saing Nasional Dalam Rangka Menghadapi Masyarakat Ekonomi Association Of Southeast Asian Nations (InPres Kesiapan MEA). Melalui InPres Kesiapan MEA, pemerintah telah menetapkan pedoman untuk peningkatan daya saing nasional dan persiapan pelaksanaan MEA dalam 14 (empat belas) strategi. Salah satu strategi yang termuat dalam InPres Kesiapan MEA adalah Pengembangan Industri Nasional, yang fokus pada:
a. Pengembangan Industri Prioritas Dalam Rangka
b. Memenuhi Pasar ASEAN;
c. Pengembangan Industri Dalam Rangka
d. Mengamankan Pasar Dalam Negeri; 
e. Pengembangan Industri Kecil Menengah;

f. Pengembangan Sumber Daya Manusia dan Penelitian;

g. Penerapan Standar Nasional Indonesia (SNI).

Sementara itu Pengembangan Tenaga Kerja fokus pada 1) Peningkatan Daya Saing Tenaga Kerja dan 2) Peningkatan kompetensi dan produktivitas tenaga kerja. Dalam kaitannya dengan industri kulit, penerapan SNI pada produk kulit dan peningkatan kompetensi Sumber Daya Manusia melalui pendidikan dan pelatihan berbasis Standar Kompetensi Kerja Nasional Indonesia (SKKNI) merupakan salah satu upaya yang dapat dilakukan untuk menghadapi MEA. MEA merupakan sebuah kesepakatan yang telah dibuat oleh Indonesia, selain menghasilkan dampak positif bagi Indonesia, juga berpeluang memberikan dampak negatif. Arus bebas barang dan tenaga kerja khususnya untuk industri kulit menjadi ancaman yang harus ditangani dengan baik. Oleh karena itu menjadi penting untuk dibahas mengenai optimalisasi kebijakan SNI pada produk kulit dan SKKNI bagi tenaga kerja dalam bidang industri kulit untuk menghadapi Masyarakat Ekonomi Asean.

Berdasarkan latar belakang masalah sebagaimana telah diuraikan di atas, maka yang menjadi rumusan masalah penelitian adalah :

a. Bagaimana optimalisasi kebijakan SNI produk kulit di Indonesia?

b. Bagaimana optimalisasi kebijakan SKKNI tenaga kerja industri kulit di Indonesia?

\section{METODE PENELITIAN}

Penelitian ini merupakan penelitian normatif dengan menggunakan pendekatan undang-undang (statute approach). Pendekatan undang-undang dilakukan dengan menelaah peraturan perundang-undangan yang bersangkut paut dengan isu SNI produk kulit, dan SKKNI tenaga kerja industri kulit untuk menyimpulkan mengenai ada atau tidaknya benturan filosofis antara peraturan perundang-undangan dengan isu yang dihadapi. Data yang digunakan dalam penelitian ini terdiri dari dari bahan hukum primer dan bahan hukum sekunder. Data tersebut kemudian dianalisa dengan menggunakan cara deskriptif kualitatif. 


\section{PEMBAHASAN}

\section{A. Optimasi Kebijakan Standar Nasional Indonesia bagi Produk Kulit di Indonesia}

Arus bebas barang merupakan salah satu elemen utama MEA. Untuk mendukung pasar tunggal dan basis produksi ASEAN, maka ditetapkan Asean Trade in Goods Agreement (ATIGA) dengan prinsip-prinsip sebagai berikut :

a. Mewujudkan kawasan arus barang yang bebas sebagai salah satu prinsip.

b. Membentuk pasar tunggal dan basis produksi dalam MEA yang dituangkan dalam cetakbiru MEA.

c. Meminimalkan hambatan dan memperkuat kerjasama di antara negaranegara anggota ASEAN.

d. Menurunkan biaya usaha.

e. Meningkatkan perdagangan, investasi dan efisiensi ekonomi.

f. Menciptakan pasar yang lebih besar untuk para pengusaha di negara-negara anggota ASEAN.

g. Menciptakan kawasan investasi yang kompetitif.

Penghapusan Non-Tarif Bariers di setiap negara anggota ASEAN merupakan salah satu komponen untuk mewujudkan kawasan arus barang yang bebas. ATIGA mendefinisikan non-tariff barriers sebagai tindakan selain tarif yang secara efektif melarang atau membatasi impor atau ekspor barang dalam negara anggota. Fakhrudin (2008 : 218 - 221) menyatakan non-tariff barriers dalam perdagangan internasional meliputi :

a. Quota, hambatan perdagangan dalam bentuk kuota impor secara eksplisit.

b. Voluntary Export Restraint, hambatan perdagangan dalam bentuk kesepakatan negara pengekspor untuk membatasi jumlah komoditas ekspornya ke negara pengimpor.

c. Persyaratan kandungan lokal, hambatan perdagangan dengan cara mensyaratkan kandungan lokal dalam produk impor.

d. Import Licenses, hambatan perdagangan dengan cara mensyaratkan adanya pemberian ijin dari setiap barang yang masuk ke dalam negeri. 
e. Import State Trading Enterprises, hambatan perdagangan dengan cara menjadikan institusi pemerintah sebagai pembeli tunggal komoditas tertentu di pasar dunia.

f. Kebijakan Manajemen Nilai Tukar, hambatan perdagangan dengan cara mengontrol nilai tukar untuk mengurangi impor dan mendorong ekspor.

g. The Precautionary Principle and Sanitary and Phytosanitary, prinsip kehati-hatian dalam perdagangan bidang kesehatan dan lingkungan hidup.

ATIGA menetapkan tahapan non-tariff barriers yang harus dilaksanakan oleh setiap negara anggota sebagai berikut :

a. Brunei, Indonesia, Malaysia, Singapura dan Thailand harus menghapus nontariff barriers dalam 3 (tiga) tahapan pada tanggal 1 Januari 20092008 , 2009 dan 2010.

b. Filipina harus menghapus non-tariff barriers dalam 3 (tiga) tahapan pada tanggal 1 Januari 2010, 2011 dan 2012.

c. Kamboja, Laos, Myanmar dan Vietnam harus menghapus non-tariff barriers dalam 3 (tiga) tahapan pada tanggal 1 Januari 2013, 2014 dan 2015 dengan fleksibilitas hingga 2018.

Dengan ratifikasi ATIGA oleh Indonesia melalui Peraturan Presiden Nomor 2 Tahun 2010 Tentang Pengesahan Asean Trade In Goods Agreement (Persetujuan Perdagangan Barang ASEAN) maka setiap perdagangan barang di Indonesia harus mengacu pada ketentuan ATIGA, termasuk menghapus non-tariff barriers. Salah satu strategi Pengembangan Industri Nasional dalam menghadapi MEA yang termuat dalam InPres Kesiapan MEA adalah penerapan Standar Nasional Indonesia (SNI). Undang-Undang Nomor 20 Tahun 2014 Tentang Standardisasi dan Penilaian Kesesuaian (UU Standardisasi) mendefinisikan Standar Nasional Indonesia (SNI) sebagai standar yang ditetapkan oleh BSN dan berlaku di wilayah Negara Kesatuan Republik Indonesia.

Standar dalam SNI adalah persyaratan teknis atau sesuatu yang dibakukan, termasuk tata cara dan metode yang disusun berdasarkan konsensus semua pihak/Pemerintah/keputusan internasional yang terkait. SNI diberlakukan secara sukarela atau wajib terhadap barang dan atau jasa, proses, sistem dan personel. Berdasarkan Pasal 21 ayat (1) Undang-Undang Standardisasi, SNI dapat 
diterapkan secara sukarela oleh Pelaku Usaha, kementerian dan/atau lembaga pemerintah nonkementerian, dan/atau Pemerintah Daerah. Pasal 24 ayat (1) Undang-Undang Standardisasi menentukan apabila berkaitan dengan kepentingan keselamatan, keamanan, kesehatan, atau pelestarian fungsi lingkungan hidup, kementerian/lembaga pemerintah nonkementerian berwenang menetapkan pemberlakuan SNI secara wajib. Ketentuan SNI yang telah diberlakukan secara wajib, tidak hanya berlaku pada barang yang diproduksi dalam negeri, tetapi juga berlaku untuk barang impor sebagaimana diatur dalam Pasal 25 ayat (4) UndangUndang Standardisasi. Dalam kaitannya dengan industri kulit, pemberlakuan SNI wajib dilakukan melalui penerbitan regulasi oleh instansi pemerintah yang memiliki kewenangan untuk meregulasi dan mengawasi peredaran produk atau dalam hal ini Kementerian Perindustrian.

Tabel 1

SNI Wajib Kulit dan Produk Kulit

\begin{tabular}{|c|c|c|c|}
\hline No & No SNI & Judul SNI & Peraturan Menteri \\
\hline 1. & SNI 7037:2009 & $\begin{array}{l}\text { Sepatu pengaman dari } \\
\text { kulit dengan sistem } \\
\text { Goodyear Welt }\end{array}$ & $\begin{array}{l}\text { 37/M- } \\
\text { IND/PER/3/2009 }\end{array}$ \\
\hline 2. & SNI 0111:2009 & $\begin{array}{l}\text { Sepatu pengaman dari } \\
\text { kulit dengan sol karet } \\
\text { cetak vulkanisir }\end{array}$ & $\begin{array}{l}\text { 37/M- } \\
\text { IND/PER/3/2009 }\end{array}$ \\
\hline 3. & SNI 7079:2009 & $\begin{array}{l}\text { Sepatu pengaman dari } \\
\text { kulit dengan sol poliuretan } \\
\text { dan termoplastik } \\
\text { poliuretan sistem cetak } \\
\text { injeksi }\end{array}$ & $\begin{array}{l}\text { 37/M- } \\
\text { IND/PER/3/2009 } \\
\text { 164/M- } \\
\text { IND/PER/12/2009 }\end{array}$ \\
\hline
\end{tabular}

Sumber : pustan.kemenperin.go.id 
Berdasarkan data Pusat Standardisasi Kementerian Perindustrian, baru terdapat 3 (tiga) SNI Wajib yang berkaitan dengan industri kulit. Dengan adanya SNI wajib sepatu pengaman dari kulit sebagaimana diatur dalam SNI 7037:2009, SNI 0111:2009, SNI 7079:2009, maka produk sepatu yang tidak memenuhi ketentuan SNI menjadi terlarang. SNI Wajib sepatu pengaman dari kulit berlaku terhadap barang di dalam negeri dan juga termasuk pula barang impor.

Berkaitan dengan kesiapan Indonesia menghadapi MEA, maka penambahan SNI secara wajib dalam industri kulit merupakan hal yang harus dipertimbangkan oleh pemerintah. Namun demikian untuk menghindarkan timbulnya anggapan hambatan dalam perdagangan, maka pengembangan SNI wajib diupayakan mengacu dan tidak menduplikasi standar internasional, memberikan kesempatan bagi pemangku kepentingan untuk memberikan tanggapan dan masukan, serta dipublikasikan melalui media yang dapat diakses secara luas (bsn.go.id). Pemerintah dapat memakai pertimbangan kepentingan keselamatan, keamanan, kesehatan, atau pelestarian fungsi lingkungan hidup dalam menambah SNI wajib industri kulit.

Penambahan SNI wajib industri kulit haruslah disesuaikan dengan kebijakan Pemerintah yang termuat dalam Peraturan Pemerintah Nomor 14 Tahun 2015 Tentang Rencana Induk Pembangunan Industri Nasional Tahun 2015-2035 (RIPIN 2015-2035). RIPIN 2015-2035 menentukan bahwa salah satu pengembangan Industri kulit, dan alas kaki untuk periode 2015-2019 dan periode 2020-2035 adalah standardisasi bahan baku untuk industri kulit dan alas kaki untuk mencegah barang impor berkualitas rendah. Selain itu RIPIN 2015-2035 juga menentukan kebutuhan teknologi dalam Industri kulit dan alas kaki berupa pengolahan kulit secara sehat dan ramah lingkungan. Dengan mengacu kepada RIPIN 2015-2035, maka penambahan SNI Wajib industri kulit dapat dilakukan antara lain untuk bidang penyamakan kulit krom, penyamakan kulit krom kombinasi, kulit bagian atas alas kaki, dan kulit imitasi.

SNI penyamakan kulit krom, menjadi standar persyaratan mutu kulit yang disamak dengan penyamak krom. SNI penyamakan kulit krom dan kombinasi, menjadi standar persyaratan mutu kulit yang disamak dengan penyamak krom dan nabati atau sintetis. SNI kulit bagian atas alas kaki menjadi standar persyaratan 
mutu dan cara uji kulit bagian atas alas kaki. SNI kulit imitasi menjadi standar persyaratan mutu dan cara uji kulit imitasi. Dengan pemberlakuan SNI wajib tersebut maka sasaran RIPIN 2015-2035 berupa standardisasi bahan baku untuk industri kulit dan alas kaki dapat tercapai. Sementara itu untuk memenuhi kebutuhan Industri kecil dan menengah maka pemerintah dapat memberlakukan SNI wajib secara sebagian atau keseluruhan dari spesifikasi teknis dan atau parameter SNI. Dengan adanya SNI wajib maka diharapkan arus barang yang bebas dalam MEA dapat dikendalikan.

\section{B. Optimalisasi Kebijakan Standar Kompetensi Kerja Nasional Indonesia bagi Tenaga Kerja Industri Kulit.}

Arus bebas tenaga kerja terampil merupakan elemen penting lainnya dalam MEA. Tenaga kerja dalam MEA hanya dikhususkan kepada tenaga kerja terampil (skilled labour), yaitu tenaga kerja yang mempunyai keterampilan atau keahlian khusus, pengetahuan, atau kemampuan dibidangnya, yang bisa berasal dari lulusan perguruan tinggi, akademisi, atau sekolah teknik ataupun dari pengalaman kerja yang dibuktikan dengan sertifikat kompetensi/ijazah (kemendag.go.id). Keahlian dan pengetahuan yang didapat dari pendidikan formal atau pengalaman kerja menentukan kategorisasi seseorang ke dalam tenaga kerja terampil. Data BPS dari tahun 2002 sampai dengan tahun 2017 menunjukkan bahwa jumlah pengangguran terbuka pada tingkat pendidikan SD, SLTP, SLTA Umum/Umum masih cukup tinggi.

\section{Grafik 1}

Penggangguran Terbuka menurut Tingkat Pendidikan, 2007- 2017

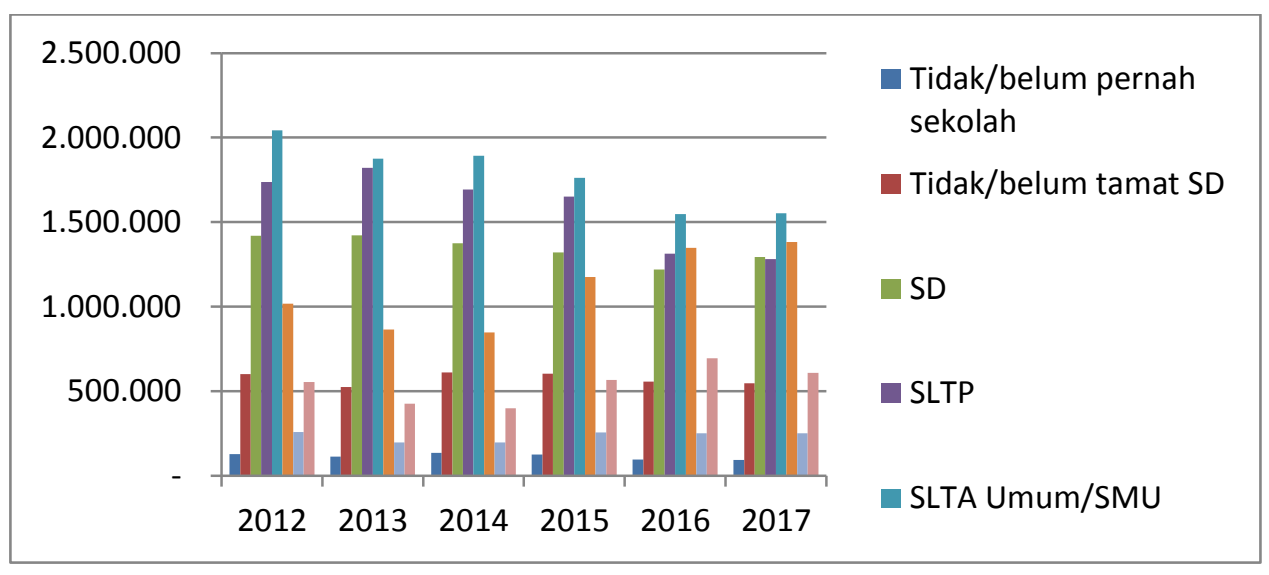

Sumber : bps.go.id (diolah) 
Masih tingginya penganguran di Indonesia bila dilihat dari tingkat pendidikan formal ini jelas sangat mengkhawatirkan. Menteri Ketenagakerjaan M Hanif Dhakiri sebagaimana dikutip oleh tribunnews.com (14/11/2017) mengatakan :

"Indonesia harus memutus lingkaran setan yang menjadi penyebab pengangguran, kemiskinan dan ketimpangan sosial. Lingkaran setan tersebut adalah kemiskinan dan pendidikan. Secara sederhana, dia mengilustrasikan seseorang miskin karena pendidikan dan kompetensinya rendah. Sehingga tak bisa mendapatkan pekerjaan yang layak. Kenapa tak bisa mendapatkan pekerjaan layak, karena tak memiliki kompetensi. Kenapa kompetensinya rendah, karena tidak mengenyam pendidikan yang cukup."

Kurangnya kompentensi tenaga kerja mengakibatkan pengangguran di Indonesia masih cukup tinggi. InPres Kesiapan MEA menentukan strategi Pengembangan Tenaga Kerja adalah 1) Peningkatan Daya Saing Tenaga Kerja dan 2) Peningkatan kompetensi dan produktivitas tenaga kerja. Sementara itu Tim Kajian Dampak ASEAN Economic Community dalam laporan Dampak Asean Economic Community terhadap Sektor Industri dan Jasa, serta Tenaga Kerja di Indonesia (53-57) mengemukakan bahwa strategi peningkatan daya saing tenaga kerja indonesia adalah dengan Pelatihan Kerja Berbasis Kompetensi dengan memperhatikan aspek (1) Regulasi, (2) Institusi Kelembagaan dan (3) Jaminan Mutu.

Dari sisi regulasi, pelatihan berbasis kompetensi diatur dalam Peraturan Pemerintah Nomor 31 Tahun 2006 tentang Sistem Pelatihan Kerja Nasional (PP Pelatihan Kerja). PP Pelatihan Kerja mendefinisikan pelatihan berbasis kompetensi adalah pelatihan kerja yang menitikberatkan pada penguasaan kemampuan kerja yang mencakup pengetahuan, keterampilan, dan sikap sesuai dengan standar yang ditetapkan dan persyaratan di tempat kerja. Sesuai dengan PP Pelatihan Kerja, program pelatihan kerja disusun berdasarkan SKKNI, Standar Internasional dan/atau Standar Khusus. Selain menjadi acuan penyusunan program pelatihan kerja, SKKNI juga menjadi acuan dalam penyusunan materi uji kompetensi.

SKKNI sendiri dapat diartikan sebagai rumusan kemampuan kerja yang mencakup aspek pengetahuan, keterampilan dan/atau keahlian serta sikap kerja yang relevan dengan pelaksanaan tugas dan syarat jabatan yang ditetapkan sesuai 
dengan ketentuan peraturan perundang-undangan yang berlaku (Pasal 1 angka 5 PP Pelatihan Kerja). Peserta pelatihan yang telah menyelesaikan program pelatihan berhak mendapatkan sertifikat pelatihan dan/atau sertifikat kompetensi kerja. Tujuan dari sertifikasi kompetensi kerja adalah untuk memberikan pengakuan secara formal terhadap kompetensi tenaga kerja.

Selain untuk pelatihan berbasis kompetensi, SKKNI juga digunakan dalam pendidikan vokasi industri berbasis kompetensi sebagaimana diatur dalam Peraturan Pemerintah Nomor 41 Tahun 2015 tentang Pembangunan Sumber Daya Industri (PP SDM Industri). PP SDM Industri mendefinisikan Pendidikan Vokasi Industri adalah pendidikan tinggi dan pendidikan menengah kejuruan yang diarahkan pada penguasaan keahlian terapan tertentu di bidang Industri. Pasal 5 PP SDM Industri menentukan Pendidikan Vokasi Industri berbasis kompetensi diselenggarakan dengan mengacu pada SKKNI di bidang Industri dan meliputi:

a. pendidikan menengah kejuruan;

b. program diploma satu;

c. program diploma dua;

d. program diploma tiga;

e. program diploma empat;

f. program magister terapan; dan

g. program doktor terapan.

Dalam kaitannya dengan industri kulit, Pendidikan Vokasi Industri berbasis kompetensi baru tersedia dalam jenjang pendidikan diploma tiga. SKKNI bidang kulit dan alas kaki menjadi acuan dalam penyusunan program pelatihan kerja berbasis kompetensi, pendidikan vokasi industri berbasis kompetensi, penyusunan materi uji kompetensi dan skema sertifikasi untuk proses uji kompetensi pada Lembaga Sertifikasi Profesi. Sesuai dengan data Kementerian Perindustrian paling tidak terdapat 3 (tiga) SKKNI yang berhubungan dengan bidang kulit dan alas kaki, yaitu :
a. SKKNI Industri Penyamakan Kulit Subbidang Proses Produksi;
b. SKKNI Industri Alas Kaki;
c. SKKNI Industri Kulit dan Kulit Buatan, termasuk Pencelupan Kulit Berbulu Kelompok Industri Pengawetan Kulit.


Dengan mengingat kebutuhan akan kesiapan tenaga kerja dalam menghadapi MEA, maka penambahan ruang lingkup SKKNI merupakan hal yang mendesak dilakukan. Sesuai dengan Peraturan Menteri Tenaga Kerja dan Transmigrasi Republik Indonesia Nomor 5 Tahun 2012 tentang Sistem Standardisasi Kompetensi Kerja Nasional (Permen SKKNI), pengembangan SKKNI harus 1) mengacu pada model Regional Model Competency Standar (RMCS) dan 2) memperhatikan perbandingan dan kesetaraan dengan standar internasional serta kemampuan penerapan di dalam negeri. RMCS dalam Permen SKKNI didefinisikan sebagai suatu model standar kompetensi yang penyusunannya menggunakan pendekatan proses kerja untuk menghasilkan barang dan jasa di industri yang telah disepakati oleh negara-negara Asia Pasifik. International Labour Organization menyatakan bahwa RMCS memiliki tiga komponen utama sebagai berikut :

a. Industry Descriptor and Coverage, deskripsi cakupan standar dalam industri atau istilah dalam sektor industri.

b. Primary Functions, fungsi dasar dalam industri untuk menghasilkan produk atau jasa.

c. Units, terdiri dari 4 sub komponen, yaitu :

1. Performance Criteria, deskripsi hasil atau out come pekerjaan;

2. Evidence requirements, standar penilaian kompetensi.

3. Critical Skills and Essential Knowledge, keahlian dan pengetahuan yang disyaratkan untuk memenuhi standar yang ditentukan.

4. Range Statement, pertimbangan peryaratan lingkungan yang ideal untuk dapat melaksanakan pekerjaan sesuai persyaratan.

Inisiasi pengembangan SKKNI dapat berasal dari masyarakat, asosiasi industri, asosiasi profesi, lembaga sertifikasi profesi, lembaga pelatihan, pemerintah dan/atau pemangku kepentingan lainnya. Untuk menindaklanjuti InPres Kesiapan MEA maka seyogyanya pemerintah menjadi pihak yang menginisiasi pengembangan SKKNI Industri kulit. Melalui pelatihan berbasis kompetensi dan Pendidikan Vokasi Industri berbasis kompetensi yang mengacu pada SKKNI maka diharapkan tenaga kerja industri kulit yang memiliki kompetensi sesuai kebutuhan industri dapat terwujud. 


\section{PENUTUP}

MEA yang mulai berlaku pada tanggal 31 Desember 2015 memberi implikasi arus bebas barang dan arus bebas tenaga kerja terampil di Indonesia. Dampak positif MEA berupa perluasan pasar dan perluasan kesempatan kerja merupakan peluang yang harus dimanfaatkan oleh Indonesia. Disamping itu dampak negatif MEA berupa serbuan barang dan tenaga kerja harus diminimalisir oleh pemerintah Indonesia. Melalui Instruksi Presiden Nomor 6 Tahun 2014 Tentang Peningkatan Daya Saing Nasional Dalam Rangka Menghadapi Masyarakat Ekonomi Association Of Southeast Asian, pemerintah telah menetapkan pedoman untuk peningkatan daya saing nasional dan persiapan pelaksanaan MEA dalam 14 (empat belas) strategi. Strategi tersebut antara lain penerapan SNI dan peningkatan kompetensi tenaga kerja.

Penerapan SNI adalah salah satu strategi dalam menghadapi arus bebas barang. Dalam kaitannya dengan arus bebas barang maka penambahan lingkup SNI Wajib dalam industri kulit menjadi hal yang harus dilakukan pemerintah. Hal ini perlu dilakukan karena SNI Wajib tidak hanya berlaku untuk barang yang berada di dalam negeri, tetapi mencakup pula pada barang impor. Namun demikian penambahan lingkup SNI Wajib Industri Kulit harus dilakukan dengan hati-hati agar tidak dianggap sebagai non-tariff barriers. Penambahan lingkup SNI Wajib industri kulit dapat dilakukan dengan memakai pertimbangan kepentingan keselamatan, keamanan, kesehatan, atau pelestarian fungsi lingkungan hidup serta dengan mengacu pada RIPIN 2015-2035. Dengan mengacu kepada RIPIN 2015-2035, maka penambahan SNI Wajib industri kulit dapat dilakukan antara lain untuk bidang penyamakan kulit krom, penyamakan kulit krom kombinasi, kulit bagian atas alas kaki, dan kulit imitasi.

Salah satu strategi antisipasi terhadap arus bebas tenaga kerja dalam MEA adalah dengan cara peningkatan kompetensi tenaga kerja industri. Dalam kaitannya dengan industri kulit, peningkatan kompetensi dilakukan melalui pelatihan berbasis kompetensi dan pendidikan vokasi industri berbasis kompetensi yang diselenggarakan dengan mengacu SKKNI Industri Kulit. Pelatihan dan pendidikan seyogyanya diikuti dengan sertifikasi kompetensi kepada peserta pendidikan dan pelatihan. Mengingat masih terbatasnya ruang lingkup SKKNI 
Industri kulit, maka penambahan ruang lingkup SKKNI merupakan hal yang harus segera ditindaklanjuti. Dengan optimalisasi kebijakan penerapan SNI dan SKKNI dalam industri kulit maka diharapkan Indonesia memiliki kesiapan yang lebih baik dalam menghadapi MEA. 


\section{DAFTAR PUSTAKA}

Direktorat Jenderal Kerjasama ASEAN. 2015. MEA dan Dinamika Ekonomi Tiongkok, India dan Dunia dalam Masyarakat ASEAN edisi 10. Jakarta : Direktorat Jenderal Kerjasama ASEAN Kementerian Luar Negeri. Diakses melalui https://www.kemlu.go.id/Majalah/ASEAN\%20Edisi\%2010.pdf

Fakhrudin, Umar. 2008. Kebijakan Hambatan Pedagangan atas Produk Ekspor Indonesia di Negara Mitra Dagang dalam Buletin Ilmiah Litbang Perdagangan Vol II. Jakarta : Badan Pengkajian dan Pengembangan Perdagangan Kementerian Perdagangan. Diakses melalui http://www.kemendag.go.id/files/pdf/2014/11/19/-1416393847.pdf

Krisnamurthi, Ina Hagniningtyas. 2015. Daerah Benah Diri Sambut MEA dalam Masyarakat ASEAN edisi 9. Jakarta : Direktorat Jenderal Kerjasama ASEAN Kementerian Luar Negeri. Diakses melalui https://www.kemlu.go.id/Majalah/ASEAN\%20Edisi\%209.pdf

International Labour Organization. 2006. Guidelines for Development of Regional Model Competency Standards (RMCS). Bangkok : International Labour Office, Diakses melalui http://www.ilo.org/wcmsp5/groups/public/---asia/--ro-bangkok/documents/publication/wcms_bk_pb_234_en.pdf

Pusat Humas Kementerian Perdagangan. 2007. Siaran Pers : Cetak-Biru Masyarakat Ekonomi ASEAN Menyongsong Era Baru Kerjasama Ekonomi ASEAN. Jakarta : Pusat Humas Kementerian Perdagangan. Diakses melalui http://www.kemendag.go.id/files/pdf/2007/11/21/cetak-biru-masyarakatekonomi-asean-id1-1353754129.pdf

2015. 100 Pertanyaan Tentang Masyarakat Ekonomi ASEAN. Jakarta : Pusat Humas Kementerian Perdagangan. Diakses melalui http://www.kemendag.go.id/addon/ebook/246/mobile/html5forpc.html

Suroso, GT. 2015. Masyarakat Ekonomi Asean (MEA) dan Perekonomian Indonesia. Jakarta: Kementerian Keuangan. Diakses melalui http://www.bppk.kemenkeu.go.id/publikasi/artikel/150-artikel-keuanganumum/20545-masyarakat-ekonomi-asean-mea-dan-perekonomian-indonesia

Tim Kajian Dampak ASEAN Economic Community. 2014. Dampak Asean Economic Community terhadap Sektor Industri dan Jasa, serta Tenaga Kerja di Indonesia. Jakarta: Kementerian Keuangan. Diakses melalui https://www.kemenkeu.go.id/sites/default/files/kajian\%20dampak\%20asean .pdf 